\title{
Uji Efektivitas Formula Pedikulosida Berbahan Aktif Minyak Atsiri Terhadap Mortalitas Kutu Kepala (Pediculus humanus capitis De Geer) Secara In Vitro
}

\author{
Tanendri Arrizqiyani $^{1}$, Khusnul ${ }^{2}$, Dewi Peti Virgianti ${ }^{3}$ \\ ${ }^{1}$ Prodi Teknologi Laboratorium Medik, STIKes Bakti Tunas Husada Tasikmalaya \\ ${ }^{2,3}$ Prodi Teknologi Laboratorium Medik, STIKes Bakti Tunas Husada Tasikmalaya \\ email : tanendriarrizqiyani@stikes-bth.ac.id
}

Tanggal Submit: 15 September 2018

Tanggal Review: 23 Oktober 2018

Tanggal Publish

Online:

29 November 2018

\begin{abstract}
Pediculosis is a disease caused by Pediculus humanus capitis de Geer or often called head lice which is an obligate ectoparasite in the human head. The prevalence of pediculosis is quite high and there are reports of resistance and negative side effects regarding the use of synthetic pediculosides trigger research and development of vegetable pediculosides. This study aims to examine the effectiveness of the formula of pediculoside with active ingredients of essential oils on head lice mortality in vitro. The study was conducted by testing 3 formulas with variations in the composition of essential oils made from cassava oil, fennel oil, lemon oil, water and vegetable glycerine. Comparison of the ingredients in formula $\mathrm{A}$ is $10 \%, 10 \%, 5 \%, 50 \%$ and $20 \%$; formula $\mathrm{B}$ is $5 \%, 15 \%, 5 \%$, $50 \%$ and $20 \%$; while formula $\mathrm{C}$ is $15 \%, 5 \%, 5 \%, 50 \%$ and $20 \%$. The test method is an experiment with a completely randomized design. The test is done by placing 10 adult head lice on filter paper which has been saturated with a formula made in a petri dish. Mortality of head lice is observed based on time. Test results data will be compared with negative controls and positive controls in the form of testing using permethrin-active pediculoside drugs. The results showed that the pediculoside formula $\mathrm{A}, \mathrm{B}$ and $\mathrm{C}$ had a high mortality rate which caused $100 \%$ of the deaths of head lice tested in less than 5 minutes. Statistically there is a significance to the results of testing formulas $\mathrm{A}, \mathrm{B}$, and $\mathrm{C}$ when compared to controls. Based on the results of multiple statistical statistics, it was found that formula $\mathrm{C}$ was the most effective as a pediculoside formula.
\end{abstract}

Keywords: Pediculus humanus capitis, minyak kayu putih, pedikulosida
PENDAHULUAN

$$
\begin{aligned}
& \text { Pedikulosis } \\
& \text { manifestasi kutu kepala (Pediculus } \\
& \text { humanus capitis de Geer) pada kepala } \\
& \text { manusia yang ditandai dengan rasa gatal }
\end{aligned}
$$

karena terjadi reaksi imunologis terhadap komponen antigen yang dihasilkan dari salivanya pada saat menghisap darah manusia. Pedikulosis seringkali dianggap penyakit yang tidak 
berbahaya, namun beberapa penelitian membuktikan bahwa kutu kepala dapat berperan sebagai vektor beberapa spesies patogen diantaranya Acitenobacter spp. penyebab peneumonia, bacterimia, endocarditis dan meningitis (Sunantraporn et al, 2015), Borrelia recurrentis penyebab louse borne relapsing fever (Boutellis et al, 2013), Rickettsia prowezekii (Robinson et al, 2003) dan Bartonella quintana penyebab trench fever (Sasaki et al, 2006).

$\begin{array}{cccc} & \text { Prevalensi } & \text { pedikulosis } & \text { yang } \\ \text { tinggi } & \text { memicu } & \text { penelitian } & \text { serta }\end{array}$
pengembangan pedikulosida atau obat pembasmi kutu kepala di berbagai negara. Obat pembasmi kutu yang banyak digunakan di berbagai negara diantaranya adalah senyawa insektisida organoklorin (DDT dan lindane), pyrehroid (permethrin dan $\delta$ phenothrin), organophosporus (malathion) dan avermectin (Gratz et al 1997; Rozendaal et al,1997; Deeks et al, 2013). Penggunaan obat pembasmi kutu yang luas dan berulang (Durand et al, 2012) serta kurang cermat (Jones et al, 2003) dapat menimbulkan resistensi yang bersifat global. Lidane dapat mengiritasi kulit, mati rasa, pusing, sakit kepala, diare, mual dan muntah, masalah pernafasan, hingga efek samping yang lebih berat, seperti kejang dan kematian, juga telah dilaporkan. FDA telah mengumumkan bahwa lindane tidak boleh digunakan sebagai pengobatan lini pertama untuk kutu dan harus digunakan dengan hati-hati pada orang dengan kondisi kulit berisiko neurotoksisitas serius (NRDC, 2012). Sedangkan permethrin juga dapat mengiritasi kulit, iritasi mata, ataksia dan kejang (National Research Council, 1994). Di Indonesia khususnya penelitian mengenai prevalensi pedikulosis dan pengobatannya belum banyak dilakukan, sehingga walaupun terdapat banyak laporan penelitian mengenai resistensi dan efek samping yang ditimbulkan, obat pembasmi kutu kepala yang dijual di Indonesia masih menggunakan senyawa aktif tersebut.

Beberapa negara telah melaporkan adanya resistensi terhadap obat pembasmi kutu konvensional yang biasa dipakai, kasus resistensi tersebut diantaranya dilaporkan di England (Downs et al, 2002), USA (Meinking et al, 2002), negara Israel (Mumcuoglu et al, 1995), Denmark (Krintensen et al, 2006), Perancis (Durand et al, 2007) dan Republik Chezh (Rupes et al, 1995). Selain resistensi, beberapa obat pembasmi kutu mempunyai efek samping yang buruk terhadap kesehatan dan lingkungan, diantaranya yaitu lindane yang dapat menimbulkan efek neurologik terhadap penggunanya dan 
menyebabkan pencemaran air

(Humphreys et al, 2008).

Di Indonesia obat pembasmi kutu yang secara luas digunakan adalah produk dengan senyawa aktif permethrin, sedangkan kasus resistensi terhadap senyawa tersebut telah banyak dilaporkan di berbagai negara di dunia, namun belum terdapat pelaporan mengenai efektivitas penggunaan maupun resistensinya di Indonesia.

Menyadari bahwa kurangnya ragam pilihan obat pembasmi kutu di Indonesia, maka terbuka peluang yang sangat besar untuk menciptakan produk obat pembasmi kutu yang teruji ampuh serta aman untuk digunakan. Untuk menciptakan formulasi obat pembasmi kutu, harus dipilih bahan dasar alami yang aman. Bahan dasar alami yang bersifat insektisida alami diantaranya yaitu minyak atsiri (Batish et al, 2008). Penggunaan minyak atsiri sebagai bahan dasar pedikulosida telah dilakukan di beberapa negara, diantaranya di Australia, Belgia dan Israel. Produk berbasis herbal tersebut mengandung senyawa aktif berupa minyak atsiri beberapa tanaman yang diformulasikan dalam bentuk sediaan lotion, sampo, spray maupun larutan. Senyawa aktif yang terkandung pada produk obat pembasmi kutu di Australia adalah meulaleuca oil, lavender oil, eucalyptus oil, lemon tree oil, geranium oil, santalum oil, thyme, rosemary, ekstrak akar Echinacea purpurea dan Canarium luzonicum gum oil (Greive et al, 2012; Barker and Altman, 2011). Di Belgia senyawa aktif yang digunakan adalah oligodecene oil dan sesame oil (Yoon et al, 2015), sedangkan di Israel menggunakan coconut oil, anise oil dan ylang-ylang oil (Mumcuoglu et al, 2002).

Pada penelitan ini akan dilakukan uji efektivitas formula pedikulosida berbahan aktif campuran minyak atsiri terhadap mortalitas kutu kepala secara in vitro. Adapun minyak atsiri yang digunakan adalah minyak kayu putih, minyak lemon dan minyak adas dengan emulsifier vegetable glycerine dan penambahan akuades sebabai pengencernya.

\section{METODE PENELITIAN}

\section{Alat dan Bahan}

Spuit, cawan petri, sisir serit, gunting, vortex, stopwatch, rak tabung, tabung reaksi, pipet tetes, spatula, beaker glass, erlenmeyer, kertas saring, minyak kayu putih, minyak adas, minyak citrus, vegetable glycerine, kutu kepala $P$. humanus capitis, aquadest, tisu, pedikulosida produk " $\mathrm{X}$ " dengan bahan aktif permethrin. 


\section{Pembuatan formula pedikulosida}

Formula pedikulosida dibuat dengan mencampurkan beberapa minyak atsiri, yaitu minyak kayu putih, minyak adas, minyak lemon. Masing-masing minyak atsiri diukur volumenya sesuai dengan resep formula yang akan dibuat, kemudian diacampur dengan akuades dan vegetable gliserin. Formula yang telah dicampur kemudian dihomogenkan dengan cara divortek. Adapun komposisi formula yang dibuat adalah sebagai berikut:

Formula A: Komposisi yang dibuat adalah $10 \%$ minyak kayu putih, $10 \%$ minyak adas, $5 \%$ minyak citrus, $50 \%$ air dan $25 \%$ vegetable glycerine.

Formula B : Komposisi formula yang dibuat adalah 5\% minyak kayu putih, 15 $\%$ minyak adas, 5\% minyak citrus, $50 \%$ air dan $25 \%$ vegetable glycerine.

Formula C : Komposisi formula yang dibuat adalah $15 \%$ minyak kayu putih, 5 $\%$ minyak adas, $5 \%$ minyak citrus, $50 \%$ air dan $25 \%$ vegetable glycerine.

\section{Pengumpulan Objek Penelitian}

Objek penelitian berupa Pediculus humanus capitis stadium dewasa dengan ciri-ciri tubuh berukuran 1-3 mm, berwarna putih abu-abu sampai kehitaman, kepala berbentuk segitiga yang mempunyai mata, sepasang antena yang terdiri dari lima ruas, dan mulut berbentuk tusuk isap. Torak terdiri dari tiga segmen dan abdomen yang terdiri dari sembilan ruas yang menyatu, mempunyai tiga pasang kaki yang dilengkapi dengan kuku. Kutu kepala dewasa dikumpulkan dari beberapa orang anak perempuan pengidap pedikulosis usia Sekolah Dasar.

\section{Pengujian Efektifitas Formula}

Uji efektifitas formula A, B dan C terhadap mortalitas kutu kepala (Pediculus humanus capitis) dewasa dilakukan secara in vitro (Greive dan Barnes, 2012; Semmler et al., 2010; Yang et al., 2004; Meinking et al., 2002) dilakukan dengan menggunting kertas saring berbentuk lingkaran sesuai dengan diameter cawan petri dan memasukkannya ke dalam cawan petri dengan memastikan bagian dasar cawan petri tertutup kertas saring secara keseluruhan. Formula A, B dan C diteteskan sebanyak $0.5 \mathrm{~mL}$ dan dipastikan tersebar merata pada kertas saring. Sebanyak sepuluh ekor kutu kepala dimasukkan ke dalam cawan petri yang berisi kertas saring yang telah formula tersebut, kemudian cawan petri tersebut ditutup. Motilitas kutu kepala diperiksa pada lima menit pertama, kemudian diperiksa setiap 5 menit. Prosedur diatas dilakukan untuk masingmasing formula dengan 4 kali pengulangan untuk setiap merk. Pada kontrol negatif, aquadest diteteskan 
pada kertas saring kemudian dilakukan prosedur pengujian seperti untuk sampel. Pada uji pembanding, produk pedikulosida " $\mathrm{X}$ " disebarkan pada kertas saring kemudian dilakukan pengujian seperti untuk sampel. Keefektifan diambil dari hasil uji formula tersebut dibandingkan dengan hasil uji produk pedikulosida " $\mathrm{X}$ ".

\section{Analisis Data}

Analisis data dilakukan dengan uji statistik dengan mengukur uji normalitas menggunakan uji ShapiroWilk kemudian diuji homogenitas data yang diperoleh, menguji signifikansi perbedaan waktu mortalitas antara hasil uji formula serta uji lanjut menggunakan uji tukey HSD untuk mengetahui perbedaan hasil antara formula A, B dan C.

\section{HASIL PENELITIAN}

Data hasil perlakuan beberapa formulasi antikutu terhadap kematian kutu kepala dianalisis menggunakan SPSS versi 20.0 untuk melakukan uji normalitas (Shapiro-Wilk) dilanjutkan dengan uji homogenitas, kemudian uji anova dan uji tukey HSD sebagai uji lanjutnya.

Uji normalitas digunakan untuk mengetahui bahwa data berasal dari populasi yang berdistribusi normal atau tidak. Hasil uji normalitas tersaji pada tabel 1 dibawah ini.

Tabel 1. Hasil Uji Normalitas sampel beberapa formulasi antikutu terhadap waktu kematian kutu kepala menggunakan SPPSS versi 20,0

\begin{tabular}{lll}
\hline Perlakukan & Shapiro- & Kesimpulan \\
& Wilk & \\
\hline Perlakuan & Nilai & Normal \\
terhadap & Sig.0,885 & \\
kematian & Nilai & \\
kutu & tetapan Sig & \\
& 0,05 & \\
\hline
\end{tabular}

Berdasarkan tabel 1 diatas diketahui bahwa hasil uji normalitas formulasi antikutu memiliki nilai signifikansi lebih besar dari tetapan signifikansi 0,05 , hal ini menunjukkan bahwa sampel data berasal dari populasi yang berdistribusi normal. Hasil tersebut kemudian dilakukan uji homogenitas, untuk mengetahui mengetahui varian dari beberapa populasi yang sama atau tidak. Berdasarkan hasil uji homogenitas, diperoleh data yang homogen, seperti yang tersaji pada tabel 2 dibawah ini.

Tabel 2. Hasil Uji Homogenitas sampel beberapa formulasi antikutu terhadap waktu kematian kutu kepala menggunakan SPPSS versi $\mathbf{2 0 , 0}$

\begin{tabular}{rrrr}
\hline $\begin{array}{c}\text { Levene } \\
\text { Statistic }\end{array}$ & df1 & df2 & Sig. \\
\hline, 102 & 2 & 9 &, 904 \\
\hline
\end{tabular}

Hasil uji homogenitas dari tabel 2 diatas, diperoleh nilai signifikansii sebesar 0,904 lebih besar dari tetatapan 
signifikasi yang sebesar 0,05. Hal tersebut menunjukkan bahwa sampel dari penelitian ini berasal dari waktu kematian kutu kepala yang sama atau homogen. Hasil tersebut memenuhi syarat untuk dilakukan uji variansi (anova) dan hasil uji anova tersaji pada tabel 3 dibawah ini.

Tabel 3. Hasil Uji anova Hasil Uji Homogenitas sampel beberapa formulasi antikutu terhadap waktu kematian kutu kepala menggunakan SPPSS versi 20,0

\begin{tabular}{lccccc}
\hline & $\begin{array}{c}\text { Sum of } \\
\text { Squares }\end{array}$ & Df & $\begin{array}{c}\text { Mean } \\
\text { Square }\end{array}$ & F & Sig. \\
\hline $\begin{array}{l}\text { Between } \\
\text { Groups }\end{array}$ & 21567,16 & 2 & 10783,58 & 13,0 &, 002 \\
$\begin{array}{l}\text { Within } \\
\text { Groups }\end{array}$ & 7454,500 & 9 & 828,278 & & \\
Total & 29021,66 & 11 & & & \\
\hline
\end{tabular}

Hasil uji anova pada tabel 3 diperoleh nilai signifikani sebesar 0,002 lebih kecil dibandingkan dengan tetapan nilai signifikansi sebesar 0,05 . Hal itu menunjukkan bahwa perlakuan beberapa formulasi antikutu berpengaruh yang signifikan terhadap waktu kematian kutu kepala. Maka dengan hasil tersebut dilakukan proses uji lanjut menggunakan uji tukey HSD seperti yang tersaji pada tabel 4 dibawah ini.

\section{Tabel 4. Hasil Uji Homogenitas sampel beberapa formulasi antikutu terhadap waktu kematian kutu kepala menggunakan SPPSS versi 20,0}

\begin{tabular}{cc}
\hline Perlakuan & $\begin{array}{c}\text { Rerata Waktu } \\
\text { Kematian }\end{array}$ \\
\hline Formula B & $214,25^{\mathrm{a}}$ \\
Formula & $144,50,5^{\mathrm{b}}$ \\
A & $112,75^{\mathrm{b}}$ \\
Formula C & 7200 \\
Kontrol + & \\
\hline Keterangan : \\
> Angka yang diikuti huruf yang sama \\
tidak berbeda pada tingkat kesalahan \\
5\%
\end{tabular}

Berdasarkan hasil uji lanjut pada tabel 4 diatas, menunjukkan bahwa terdapat perbedaan yang sangat nyata antara formula $\mathrm{C}$ dengan formula $\mathrm{A}$ dan B. Hal itu menunjukkan bahwa Formula C dengan komposisi 15\% minyak kayu putih, $5 \%$ minyak adas, 5\% minyak citrus, $50 \%$ air dan $25 \%$ vegetable glycerine mampu mematikan kutu kepala paling cepat dibandingkan dengan formula yang lain dengan rerata waktu kematian 112,75 detik, sedangkan formula A dan Formula B tidak memiliki perbedaan yang sangat nyata terhadap pengaruh kematian kutu kepala dengan rerata waktu kematian masingmasing 144,50 detik dan 214,25 detik. Pengaruh dari beberapa formula tersebut apabila dibandingkan dengan kontrol dari obat kutu kepala, hasilnya jauh lebih cepat dalam mematikan sampel, kontrol mampu mematikan selama 2 jam atau 7200 detik. 


\section{PEMBAHASAN}

Minyak atsiri memiliki aktivitas biologi terhadap serangga yang bersifat menolak, menarik, racun kontak, racun pernafasan, mengurangi nafsu makan, menghambat peletakan telur, menghambat petumbuhan, serta menurunkan fertilitas (Isman, 2000), termasuk terhadap kutu kepala (Burgess, 2004). Penggunaan minyak atsiri sebagai formula pedikulosida nabati sangat berpotensi karena beberapa minyak atsiri bersifat selektif dan mempunyai efek samping yang sedikit terhadap organisme yang bukan sasarannya sehingga aman digunakan (Mumcuoglu et al., 2002). Disamping itu sifat minyak atsiri yang kandungannya misalnya monoterpenoid sangat mudah diekstraksi dan dibiodegradasi, selain itu sudah umum digunakan sebagai agen pewangi dan perasa serta pengawet pada makanan dan minuman sehingga menjadi kanditat yang sangat bagus dan efektif sebagai insektisida (Toloza et al. 2010; Marimuthu et al. 2012; Regnault-Roger and Arnason 2013).

Berdasarkan data hasil penelitian dan uji statistika bahwa formula yang paling efektif adalah formula $\mathrm{C}$, dimana komposisi minyak atsiri yang dibuat adalah 15\% minyak kayu putih; 5\% minyak adas; $5 \%$ minyak lemon. Apabila dilihat dari parameter waktu kematian pada Formula A dan B terlihat bahwa formula A lebih cepat dibandingkan dengan formula $\mathrm{B}$. Komposisi yang berbeda dari ketiga formula tersebut adalah persentase minyak kayu putih dan minyak adas, sedangkan persentase minyak lemon adalah sama pada semua formula dan ditambahkan sebagai penambah aroma. Pada formula yang mempunyai kandungan minyak kayu putih lebih tinggi cenderung memiliki waktu mematikan yang lebih cepat. Formula C yang memiliki kandungan kayu putih $15 \%$ memiliki waktu tercepat, disusul oleh formula A yang memiliki kandungan minyak kayu putih $10 \%$, sedangkan formula $\mathrm{C}$ memiliki waktu yang paling lama dengan kandungan minyak kayu putih hanya $5 \%$.

Minyak kayu putih memiliki kandungan 1,8-sineol yang merupakan senyawa monoterpen oksida sebagai kandungan utamanya, sedangkan minyak adas memiliki kandungan utama anise camphor yang merupakan fenilpropanoid (Yones et al, 2016). Tingkat okseigenasi dari minyak atsiri dapat berpengaruh terhadap properti psikokimia yang mempengaruhi aktivitas kutu kepala. Senyawa mono teroksigenasi yang mempunyai stuktur sederhana seperti alcohol, keton atau fenol yang merupakan grup fungsional terbukti yang paling aktif melawan kutu 
kepala. Terpinen-4-ol menunjukkan senyawa paling efektif melawan kutu kepala, diikuti oleh senyawa monosiklik mono-teroksigenasi lainnya (Priestley et al, 2009). Namun, faktor lainnya seperti interaksi antar senyawa penyusun pun dapat berpengaruh terhadap aktivitas formula secara keseluruhan (Burgess, 2004).

Mode of delivery dari minyak atsiri dan senyawa yang terkandung di dalamnya adalah melalui penghirupan uap yang menyebabkan terhambatnya sistem respirasi. Minyak atsiri tersebut merupakan campuran komplek berbagai komponen yang bervariasi tingkat lifofilik, hidrofilik dan volatilnya pada suhu ruang (Yang et al, 2005). Komponen terpenoid pada minyak atsiri mempunyai berat molekul yang sangat rendah sehingga bisa beraksi secara mekanik yaitu dengan menembus kutikula kutu sampai ke trakea yang dapat menyebabkan kutu kepala mati lemas karena tidak bisa bernafas. Keefektifan penggunaan minyak atsiri ini dapat diakibatkan oleh kombinasi efek langsung melalui penyerapan di kutikula dan melalui penyerapan tidak langsung dari uapnya (Di Campli et al, 2012).

Jika dibandingkan dengan hasil dari pengujian menggunakan kontrol dengan produk pedikulosida yang berbahan aktif permethrin sebagai pembanding, waktu kematian yang diperoleh pada pengujian formula A, B dan C sangatlah signifikan berbeda, yaitu lebih cepat daripada kontrol. Waktu yang dibutuhkan oleh formula C adalah 112,75 detik sedangkan pada kontrol 7200 detik. Menurut Yang et al (2004) hal tersebut disebabkan karena kebanyakan minyak atsiri mempunyai sifat mudah menguap karena kandungan senyawa volatilnya sehingga aktivitas kontak terhadap kutu kepala lebih baik, sedangkan zat aktif permethrin hanya melalui penyerapan langsung pada kutikula saja saja.

\section{SIMPULAN DAN SARAN}

\section{Simpulan}

Berdasarkan penelitian ini dapat disimpulkan bahwa formula pedikulosida $\mathrm{C}$ secara signifikan paling efektif membunuh kutu kepala secara in vitro.

\section{Saran}

Formulasi yang dihasilkan dari penelitian ini dapat dikembangkan untuk pengujian praklinik secara in vivo seperti uji toksisitas dan uji iritasi agar dapat diaplikasikan menjadi formula yang efektif, stabil dan aman pada manusia. 


\section{UCAPAN TERIMAKASIH}

Peneliti mengucapkan terimakasih kepada: Direktorat Riset dan Pengabdian kepada Masyarakat (DRPM) DIKTI melalui SIMLITABMAS yang telah mendanai $100 \%$ penelitian ini.

\section{DAFTAR PUSTAKA}

Barker SC and Altman PM. 2011. An ex vivo,assesor blind, randomised, parallel group, comparative efficacy trial of the ovicidal activity of three pediculicides after a single application meulaleuca oil and lavender oil and lemon tea tree oil, and a "suffocation" pediculicide. BMC Dermatology. 11 : 14. http://www.biomedcentral.com/14 71-5945/11/14.

Boutellis A, Mediannikov O, Bilcha KD, Ali J, Campelo D, Barker S, Raoult D. 2013. Borrelia recurrentis in head lice, Ethiophia. Emerging Infectious Disease. 19(5): 796-798. www.cdc.gov/eid.

Burgess IF. 2004. Human lice and their control. Ann Rev Entomol 49: 457-481.

Deeks LS, Naunton M, Currie MJ, Bowden FJ. 2013. Topical ivermectin $0,5 \%$ lotion for treatment of head lice. Ann Pharmacother. 47(9): 1161-7. DOI:

10.1177/1060028013500645.

Di Campli ED, Bartolomeo SD, Pizzi PD, GiulioMD, Grande R, Nostro A, Cellini L. 2012. Activity of tea tree oil and nerolidol alone or in combination against Pediculus capitis (head lice) and its eggs. Parasitol Res 111:1985-1992.
Downs AM, Stafford KA, Hunt LP, Ravenscroft JC, Coles GC. 2002. Widespread Insecticide Resistence in Head Lice to The Over-The Counter Pediculocides in England, and The Emergence of Carbaryl Resistance. $\mathrm{Br} \mathrm{J}$ Dermatol.146:88-93.

Durand R, Bouvresse S, Berdjane Z, Izri A, Chosidow $\mathrm{O}$ and Clark JM. 2012. Insecticide resistance in head lice: clinical, parasitological and genetic aspects. Clin Microbiol Infect. 18: 338-344. 10.1111/j.14690691.2012.03806.x.

Durand R, Millard B, Bouges-Michel C, Bruel C, Bouvresse S, Izri A. Detection of pyrethroid resistance gene in head lice in schoolchildren from Bobigny, France. J Med Entomol. 2007:44:796-8. PubMed DOI: $10.1603 / 0022-$ 2585(2007)44[796:DOPRGI]2.0. $\mathrm{CO} ; 2$

Gratz NG. 1997. Humanlice: their prevalence, control and resistance to insecticides-a review 1985Đ1997. World Health Organization, Geneva, Switzerland, WHO/CTD/WHOPES/97.8.

Greive KA and TM Barnes. 2012. In Vitro Comparison of Four Treatments Which Discourage Infestation by Head Lice, Parasitol Res. 110:1695-1699.

Humphreys EH, Janssen S, Heil A, Hiatt P, Solomon G and Miller MD. 2008. Outcomes of the california ban on pharmaceutical lindane: clinical and ecological impacts. environmental heallth perspective. 116 (3): 297-302. 
Isman, M. B. 2000. Plant Essential Oils for Pest and Disease Management, Crop Protection. 19:603-608.

Jones KM and English III JG. 2003. Review of common Theurapeutic Options in The United Sates for The Treatment of Pediculosis capitis. Clinical Infections Deases. 36: $1355-61$.

Kristensen M, Knorr M, Rasmussen AM, Jespersen JB. 2006. Survey of permethrin and malathion resistance in human head lice populations from Denmark. J Med Entomol. 43: 533-538.

Marimuthu S, Rahuman AA, Santhoshkumar T, Jayaseelan C, Kirthi AV, Bagavan A, Kamaraj C, Elango G, Zahir AA, Rajakumar G, Velayutham K. 2012. Lousicidal activity of synthesized silver nanoparticles using Lawsonia inermis leaf aqueous extract against Pediculus humanus capitis and Bovicola ovis. Parasitol Res 111: 20232033

Meinking TL, Serrano L, Hard B, Entzel P, Lemard G, Rivera E. 2002. Villar ME Comparative in Vitro Pediculicidal Efficacy of Treatments in a Resistant Head Lice Population in the United States, Arch Dermatol. 138:220224.

Mumcuoglu KY, Hemingway J, Miller J et al. 1995. Permethrin resistance in the head louse Pediculus capitis from Israel. Med Vet Entomol. 9: 427-432.

Mumcuoglu KYJ, Miller C, Zamir G, Zentner V, Helbin and A Ingber. 2002. The In Vivo Pediculicidal Efficacy of Natural Remedy,Isr, Med, Assoc, J. 4:790-793.
Mustarichie, R, Musfiroh, I dan Levita, J. 2011. Penelitian Kimia Tanaman Obat, Widya Padjajaran; Bandung.

National Research Council. 1994. Health Effects of PermethrinImpregnated Army Battle-Dress Uniforms. Washington, DC: The National Academies Press. DOI:10.17226/9274.

Natural Resources Defense Council NRDC. 2012. Health Facts: When the Treatment is Toxic: Pesticides in Head Lice Prescriptions. NRDC The Earth's Best Defense. https://www.nrdc.org/sites/default /files/lindane.pdf (Diaksestanggal 13 April 2016).

Priestley CM, Burgess IF, Williamson EM. 2006. Lethality of essential oil constituents towards the human louse, Pediculus humanus, and its eggs. Fitoterapia 77:303309.

Regnault-Roger VC, Arnason JT. 2013. Essential oils in insect control: low-risk products in a high-stakes world. Annu Rev Entomol 57: 425-424.

Robinson D, Leo N, Prociv P, Barker SC. 2003. Potential Role of Head Lice Pediculus humanus capitis as Vectors of Rickettsia porwazekki. Parasitol Res. 90(3):209-11.

Rozendaal, JA. 1997. Methods for use by individuals and communities. World Health Organization, Geneva, Switzerland.

Rupes V, Moravec J, Chmela J, Ledvinka J, Zelenkova J. 1995. A resistance of head lice (Pediculus capitis) to permethrin in Czech Republic. Cent Eur J Public Health. 3: 30-32. 
Sasaki T, Poudel SKS, Isawa H, Hayashi T, Seki N, Tomita T, Sawabe K, Kobayashi M. 2006. First molecular evidence of Bartonella Quintana in Pediculus humanus capitis (Phthiraphtera: Pediculidae), collected from Nepalese children. J. Med. Entomol. $\quad 34(1)$ : 110-112. http://jme.oxfordjournal.org.

Semmler M, Abdel Ghaffary, AlRasheid K, Klimpel S, Mehlhom H. 2010. Reppelency Against Head Lice (Pediculus humanus capitis), Parasitol Res. 106:729731.

Sunantaporn S, Sanpraset V, Pengsakul $\mathrm{T}$, Phumee A, Boonserm R, Tawatsin A, Thavara U, Siriyasatien P. 2015. Molecular survey of the head louse Pediculus humanus capitis in Thailand and its potential role for transmitting Acinetobacter spp. Parasites \& Vector. 8: 127. DOI: 10.1186/s13071-015-0742-4.

Toloza AC, Zygadlo J, Mougabure Cueto G, Biurrun F, Zerba E, Picollo MI. 2006. Fumigant and repellent properties of essential oils and component compounds against permethrin-resistant Pediculus humanus capitis (Anoplura: Pediculidae) from Argentina. J Med Entomol 43:889-895.

Yang YC, Lee HS, Clark JM, Ahn YJ. 2004. Insecticidal Activity of Plant Essential Oils Against Pediculus humanus capitis (Anoplura: Pediculidae), J Med Entomol 41:699-704.
Yones DA, Bakir HY, Bayoumi SAL. 2016. Chemical composition \& efficacy of some selected plant oils against Pediculus humanus capitis in vitro. Parasitol Res. DOI 10.1007/s00436-016-5083.5.

Yoon KS, Ketzis JK, Andrewes SW, Wu CS, Honraet K,Staljanssens D, Rossel B, Clark JM. 2015. In vitro and in vivo evaluation of infestation deterrents against lice. vector control, pest management, resistance, repellents. J. Med. Entomol. 52 (5): 970-978. DOI: 10.1093/jme/tjv069. 